\title{
Lawikan Kera Ngalam di Tengah Arus Globalisasi
}

\author{
Iin Rachmawaty
}

\begin{abstract}
Abstrak
Kebudayaan yang kita kenal sangat khas Malang dan masih terus bertahan meski banyak dihantam berbagai macam kebudayaan luar adalah bahasa prokem atau yang lebih dikenal dengan sebutan bahasa walikan, dan Arek Malang menyebutnya dengan istilah "Lawikan Kera Ngalam”. Orang asli Malang sering sekali berkomunikasi menggunakan bahasa walikan ini dan tampaknya karena saking terbiasanya, mereka langsung bicara tanpa berpikir terlebih dahulu. Bila kita bukan orang asli Malang, maka tentunya kita akan merasa kesulitan memahami apa yang orang bicarakan. Bahasa prokem ini sendiri telah menjadi suatu kebanggaan Arek Malang sehingga di manapun mereka berada, mereka akan selalu berusaha untuk tidak menghilangkan ciri khas daerah asal mereka dengan melakukan percakapan menggunakan bahasa prokem. Selain itu, penggunaan bahasa prokem bagi arek Malang adalah suatu penanda identitas dan sebagai suatu media yang mengakrabkan satu dan lainnya.
\end{abstract}

\section{Kata Kunci}

Globalisasi, Malang, walikan, bahasa, prokem

\section{Pendahuluan}

Menurut asal katanya, kata "globalisasi" diambil dari kata global, yang maknanya adalah universal. Jika menilik pendapat dan pemahaman dari berbagai tokoh, maka dapat dikatakan bahwa pada dasarnya globalisasi itu memiliki banyak penafsiran tergantung dari sudut pandang mana kita melihat. Sebagian orang menafsirkan globalisasi sebagai proses pengecilan dunia atau menjadikan dunia sebagaimana layaknya sebuah perkampungan kecil. Sedangkan sebagian lainnya menyebutkan bahwa globalisasi merupakan suatu upaya penyatuan masyarakat dunia dari sisi gaya hidup, orientasi, dan budaya.

Di era globalisasi sekarang ini masalah yang paling penting mendapat perhatian adalah masalah identitas kebangsaan. Seperti kita semua tahu bahwa derasnya arus globalisasi menyebabkan kian terkikisnya nilai-nilai kebangsaan. Anak-anak lebih bangga dengan budaya asing daripada budaya bangsanya sendiri. Slogan "Aku Cinta Produk Indonesia" sepertinya hanya menjadi ucapan belaka, tanpa ada aksi yang mengikuti pernyataan tersebut. Dengan keadaan yang seperti ini, maka sangatlah perlu ditanamkan nilai-nilai nasionalisme dan kecintaan pada budaya lokal agar jati diri bangsa kita tidak semakin tergerus oleh budaya global yang terus mendominasi dan menghegemoni baik secara implisit maupun secara eksplisit. 


\section{Pembahasan}

Pada dasarnya, globalisasi adalah sebuah proses kultural yang tidak bisa ditolak oleh semua negara di dunia, termasuk Indonesia. Terlebih lagi, perkembangan teknologi informasi dan ilmu pengetahuan dikuasai oleh negara-negara maju dengan kapital besar, bukan negaranegara berkembang seperti Indonesia. Sehingga kenyataan ini melahirkan suatu bentuk pemikiran tentang masyarakat yang mau dan mampu menerima serbuan globalisasi, dan ada masyarakat yang menolak globalisasi. Adapun mereka yang menolak biasanya adalah: Pertama, mereka yang termasuk kelompok masyarakat yang belum mapan atau belum siap menerima perubahan. Kedua, kelompok masyarakat yang tertinggal atau terasing yang merasa terancam dengan adanya pengaruh dari luar daerahnya. Ketiga, adalah kelompok masyarakat dari kalangan generasi tua yang cenderung 'mencurigai' globalisasi sebagai alasan yang bisa merusak moral luhur bangsa. Masyarakat Indonesia termasuk pada kelompok masyarakat yang pertama, masyarakat yang cenderung belum siap dalam hal sumber daya manusia. Segala sesuatu yang sifatnya berkaitan dengan teknologi dan ilmu pengetahuan masih banyak dikuasai oleh orang / perusahaan asing.

Dalam perkembangan selanjutnya, masyarakat Indonesia adalah salah satu contoh masyarakat yang majemuk dalam berbagai aspek kehidupannya. Hal ini bisa dilihat dari keanekaragaman suku dan budaya, lingkungan alam, sampai pada wilayah geografisnya yang terdiri atas ribuan pulau. Sehingga dunia mengenal Indonesia sebagai negara yang kaya akan bentuk-bentuk kebudayaan tradisional. Aneka ragam kebudayaan lokal itu bila dikembangkan dengan baik akan menjadi kekayaan budaya nasional yang tak ternilai harganya. Bangsa-bangsa besar dan maju di seluruh dunia berangkat dari akar kebudayaan lokalnya masing-masing. Jadi, sebenarnya jika kita mampu mengembangkan kekayaan budaya tradisional kita, maka hal itu akan bisa melejitkan nama Indonesia dalam kebudayaan dunia.

Hal penting yang perlu dicermati adalah bahwa ternyata masih ada kebudayaan tradisional Indonesia yang masih tetap bertahan dan masih terus menunjukkan ke-eksisannya. Jika berbicara tentang apa saja kebudayaan tradisional yang masih tetap bertahan, tentunya akan sangat banyak. Maka, dalam makalah ini akan difokuskan pada kebudayaan lokal Jawa Timur, tepatnya di kota Malang.

Di kota dingin yang terkenal dengan julukannya sebagai kota Apel ini, sering dijumpai sejumlah acara yang berkaitan dengan kekayaan budaya lokalnya. Di antaranya yang cukup terkenal dan banyak mendatangkan turis baik turis domestik yang berasal dari Malang dan sekitarnya dan dari luar kota maupun turis mancanegara dari berbagai belahan dunia, adalah Festival Malang Kembali dan Festival Malang Tempo Doeloe.

Sementara itu, kebudayaan yang sangat khas Malang dan masih terus bertahan meski banyak dihantam berbagai macam kebudayaan luar adalah bahasa prokem atau yang lebih dikenal dengan sebutan bahasa walikan, dan Arek Malang menyebutnya dengan istilah "Lawikan Kera Ngalam". Orang asli Malang sering sekali berkomunikasi menggunakan bahasa walikan ini dan tampaknya karena saking terbiasanya, mereka langsung bicara tanpa 
berpikir terlebih dahulu. Bila kita bukan orang asli Malang, maka tentunya kita akan merasa kesulitan memahami apa yang orang bicarakan.

Beberapa contoh bahasa walikan ini misalnya : tahes (sehat), kadit kane (tidak enak), kadit ojir (tidak punya uang), ebes (ayah), kera ngalam (arek Malang), dan yang paling unik ketika menyebut ibu, bukan kata ubi yang digunakan melainkan ebes kodew (yang artinya ebes wedok atau ayah perempuan bila di bahasa Indonesiakan).

Bahasa prokem yersebut hingga saat ini masih sering digunakan oleh orang-orang asli Malang dalam berkomunikasi sehari-hari. Uniknya, generasi mudanya masih banyak yang dijumpai menggunakan bahasa prokem dalam percakapan sehari-hari dengan temanteman sebaya mereka. Bahasa prokem ini sendiri telah menjadi suatu kebanggaan dan identitas diri dari orang asli Malang atau yang lebih dikenal dengan sebutan Arek Malang sehingga di manapun mereka berada, mereka akan selalu berusaha untuk tidak menghilangkan ciri khas daerah asal mereka dengan melakukan percakapan menggunakan bahasa prokem. Selain itu, penggunaan bahasa prokem bagi Arek Malang adalah suatu penanda identitas dan sebagai suatu media yang mengakrabkan satu dan lainnya.

Bahasa walikan khas Malang ini juga banyak disebut sebagai salah satu bahasa gaul daerah yang dimiliki oleh Indonesia selain bahasa dagadu di Jogja, bahasa Pacitan, dan bahasa Suroboyoan. Banyak yang mengira bahasa Malang-an adalah sama dengan boso walikan (bahasa yang kata-katanya dibalik). Padahal boso Malangan tidak sama dengan bahasa walikan, karena bahasa Malangan tidak mempunyai pakem (aturan) tertentu sebagaimana umumnya bahasa prokem.

Bahasa Malangan sesungguhnya adalah bahasa sleng, yang semula terbentuk dari sleng-sleng yang ada di Kota Malang. Misalnya untuk kata bohong, semula dipakai kata walikan "ngohob", tapi sejak awal tahun 1970-an muncul kata "pesi" yang semula dipakai anak-anak muda dari sleng Kayutangan. Kemudian muncul kata "awad" yang semula dipakai oleh anak-anak muda dari sleng Sawahan. Dua kata tersebut, "pesi" dan "awad", sama-sama mempunyai arti bohong. Sejak itu, dua kata dari sleng kayutangan dan sawahan tersebut dipakai secara umum oleh arek-arek Malang. Sehingga untuk mengatakan: "Kamu bohong", tidak lagi dengan kalimat; "Umak ngohob". Tapi dengan kalimat ; "umak awad" atau "umak pesi".

Hal tersebut di atas sekedar sebagai contoh, maka dari itu dari ciri-ciri pemakaian kata inilah arek-arek Malang se-Indonesia kalau bertemu di manapun, maka akan segera mengetahui sedang bertemu dengan Arek Malang asli atau tidak. Contoh lainnya: untuk sebutan orang tua ada dua yaitu "ebes" dan "genaro kewut". Walaupun dua kata ini mempunyai makna yang sama, tetapi penggunaannya memiliki konteks yang berbeda.

Untuk menyebutkan orang tua sendiri atau orang yang dituakan dan dianggap orang tua sendiri atau untuk suatu keakraban dan sebagai tanda persahabatan, menggunakan kata "Ebes". Misalnya: "ebes nganal" = bapak (kandung); ebes kode(w) = ibu (kandung). Biasa dipakai pula untuk menyebutkan orang lain yang dituakan dan dianggap orang tua sendiri misalnya "ebes sugiyono" (mantan Walikota Malang). Akan tetapi untuk mengatakan orang tua yang belum dikenal selalu dengan menggunakan kata "genaro kewut" . Misalnya: "orang 
tua itu kasihan ya?", maka kalimat yg dipakai bukan "Ebes iku naisak yo?" tetapi dengan kalimat; "Genaro kewut iku naisak yo?".

Contoh lainnya lagi: Untuk menyebutkan istri harus menggunakan kata "ndewor", bukan dengan kata "ojob", karena keduanya mempunyai perbedaan makna yang cukup signifikan. Kata "ojob" mempunyai makna sebagai pacar/gendakan (WIL). Sekarang coba Anda balik kata "ndewor" ini, maka tidak akan mempunyai makna apa-apa, karena kata tersebut asal-usulnya lahir dari salah satu daerah sleng di Malang, kemudian menjadi semacam kesepakatan komunikasi sosial kalau menyebut istri mesti dengan kata "ndewor" dan bukan dengan kata "ojob". Bukti lain bahwa bahasa Malangan bukan bahasa walikan antara lain, kata "saudara" seharusnya dibalik menjadi "araduas". Tapi jika anda mengatakan kata "araduas" ketika berkomunikasi orang Malang asli yang paham bahasa Malangan maka anda akan ditertawakan karena anda pasti bukan Arek/orang Malang asli. Bahasa sleng Malang-an untuk kata "saudara" bukan dengan kata "araduas" tapi dengan kata "arades". Demikian juga misalnya untk menyebutkan "wanita cantik/ayu", kalau hanya sekedar bahasa walikan maka mengatakannya seharusnya dengan kata "kodew uya", namun untuk arek Malang akan menyebut kalimat "kodew sarik".

Karena begitu banyak kata-kata walikan khas Malang yang tercipta, maka warga asli Arema memutuskan untuk membuat semacam kamus mini bahasa walikan. Hal ini dimaksudkan untuk melestarikan keanekaragaman bahasa mereka yang unik, juga agar orang dari luar Malang pun bisa ikut mempelajari bahasa khas mereka. Dan isi dari kamus mini tersebut adalah sebagai berikut :

A

A - partikel untuk kata tanya contoh 'iyo a?' (apa iya?), 'mrono a?' (kesana?) dst

Adapes - sepeda

Adapes rotom - sepeda motor

Ambek - dengan, dan

Amrin - pacar, kekasih

Aranjep - penjara

Arema - Arek Malang

Arodam - Madura

Arudam - Madura

Asaib - biasa

Asrob - minum

Atrakaj - Jakarta

Atret - mundur

Aud - dua

Ayarabus -Surabaya

Ayas - saya

Ayem - melempem
B

Balon / Nolab - pelacur

Bes - kependekan 'ebes'

C

Cik - ungkapan 'betapa' atau penyangatan spt 'cik gedhene' (besar banget)

Cikno - biarkan

$\mathrm{D}$

Dhulin - main

E

Ebes - bapak, panggilan hormat tidak formal

Ebes kanal - bapak

Ebes kodew - ibu

Embong - jalan

Ewed - sendiri

Ewedan - sendirian 
G

Gak - tidak

Gak main - tidak becus, tidak beres

Genaro - orang

Genok - tidak ada

$\mathrm{H}$

Halak - kalah

Halokes - sekolah

Hamur - rumah

Helob - boleh

Hewod - bibir tebal

Holopes - sepuluh

Hulupes - sepuluh

I

Ibar - kawin, nikah

Idrek - pekerjaan

Iko - itu (jarak jauh)

Ilep - alat kelamin laki-laki

Itreng - mengerti, paham

$\mathrm{J}$

Jancik - makian halus

Jancuk - makian kasar

Jès - guys, coy

K

Kadit - tidak

Kampes - celana dalam

Kana - anak

Kanyab - banyak

Kanyab tulum - banyak omong

Keat - tahi, makian

Kendho - bodoh

Kenthu - bodoh, ber ${ }^{* * * * *} \mathrm{~h}$

Kèr - guys, coy

Kèra - (arek) orang

Kètam - mati

Kèwut - tua

Kimpet - alat kelamin wanita
Kipa - baik

Kiwal - balik

Kiwalan - walikan, terbalik

Kodew - perempuan

Koen - kamu

Koleng - mabuk

Koyes - menipu

Kubam - mabuk

Kunam - burung, alat kelamin laki-laki

$\mathrm{L}$

Landas - sandal

Latab - batal

Lecep - pecel

Libom - mobil

Licek - kecil

Likis - kaki

M

Main - becus, bermain

Menclek - gila

Mengong - gila, bloon

$\mathrm{N}$

Nakam - makan

Nawak - kawan

Nawak ewed - kawan sendiri

Nayamul - lumayan

Ngalam - Malang

Ngalup - pulang

Nganal - laki-laki

Nganem - menang

Ngarames - Semarang

Ngayambes - sembahyang, sholat

Ngentit - mencuri

Ngetem - hamil

Ngingub - bingung

Ngoceb - banci, bencong, waria, pondan

(kata tetangga sebelah)

Niliki (nili’i) - mencicipi

Nolab - pelacur 
Nyelang - meminjam

$\mathrm{O}$

Oges - nasi

Ojir - uang

Ojob - suami/istri, pacar

Ojrit - iya

Omil - lima

Onit - Cina

Orip - berapa

Oskab - bakso

Osob - bahasa

Osob kiwalan - bahasa terbalik

Osi - bisa

Otos - soto

Oyi - iya

$\mathrm{P}$

Plembungan - balon

$\mathrm{R}$

Raijo - uang

Rudit - tidur
S

Sam - panggilan untuk laki2

Sèdeb - monyet

Silup - polisi

Sinam - manis (untuk menyebut gadis cantik)

$\mathrm{T}$

Tahes - sehat

Tahil - lihat

Tènyom - monyet

Tèwur - ruwet, complicated

U

Ubab - babu, pembantu

Ubir - ribu

Ublem -masuk

Uklam - jalan

Uklam-uklam - jalan-jalan

Ukut - beli

Umak - kamu

Unyap - punya

Utem - metu

W

Wanyik - orang (sebutan untuk orang ketiga, biasanya wanita)

Sampai saat ini bahasa walikan ini populer dipergunakan oleh anak muda Malang. Menurut sejarah asal muasal bahasa walikan dimulai pada saat jaman perjuangan Gerilya Rakyat untuk mempertahankan proklamasi kemerdekaan. Eksistensi bahasa walikan pada saat itu berfungsi sebagai alat komunikasi rahasia antar sesama pejuang dan sekaligus menjadi identitas untuk mengenal siapa kawan dan siapa lawan. Bahasa walikan ternyata efektif dipergunakan pada saat perjuangan proklamasi dikarenakan banyak mata-mata Belanda yang juga menggunakan bahasa Jawa.

Jadi dengan penggunaan bahasa walikan akan meminimalisir bocornya strategi perjuangan para gerilyawan ke tangan penjajah Belanda. Bahasa walikan bukanlah sebuah kata sandi karena bahasa ini sifatnya terbuka, kaya perbendaharaan kata, sekaya bahasa yang ada. 


\section{Simpulan}

Era globalisasi yang menyebar bagai virus ke seluruh dunia tentunya selain membawa dampak positif juga membawa dampak negatif. Sehingga dalam menyikapi gelombang tsunami yang bernama globalisasi tentunya kita harus bisa berpikir dan bersikap kreatif dalam arti berpikir lokal namun tetap bisa bersikap global.

Adalah suatu hal yang tidak mungkin bila kita harus menghindari atau menolak pengaruh kebudayaan global yang terus menerus menerjang kita dari berbagai sektor kehidupan, namun kita masih bisa membentengi diri dari pengaruh negatif dengan cara tetap berusaha melestarikan dan tidak melupakan kebudayaan lokal kita yang adi luhung. Bangsa yang besar dan maju adalah bangsa yang tetap mempertahankan nilai-nilai tradisional dan berangkat dari kebudayaan lokal sebagai akar dari kebudayaan nasional.

\section{Daftar Pustaka}

Barnard, Alan. 2009. History and Theory in Anthropology. New York: Cambridge University Press.

Geertz, Clifford. 1992. Tafsir Kebudayaan. Yogyakarta: Kanisius.

Koentjaraningrat. 1974. Kebudayaan, Mentalitas, dan Pembangunan. Jakarta: Gramedia Pustaka Utama. 2009. Pengantar Ilmu Antropologi. Jakarta: Rineka Cipta.

Pa Eni, Mukhlis. 2009. Sejarah Kebudayaan Indonesia. Jakarta: Rajawali Pers.

Mulyana. 2009. Demokrasi dalam Budaya Lokal. Jakarta: Gramedia Pustaka Utama.

Murniatmo, Gatut. 2000. Khazanah Budaya Lokal: Sebuah Pengantar untuk Memahami Kebudayaan Daerah di Nusantara. Jakarta: Adicita.

Smiers, Joost. 2009. Arts Under Pressure: Memperjuangkan Keanekaragaman Budaya di Era Globalisasi. Jakarta: INSIST Press.

Sutrisno, Mudji. 2008. Filsafat Kebudayaan: Ikbtiar Sebuah Teks. Jakarta: Hujan Kabisat. http://www.infokepanjen.com/2011/03/profil-kerajinan-topeng-malang.html http://www.zimbio.com/member/rke313/articles/6256692/dari+buku+interpretation+culture +clifford

http://www.simpuldemokrasi.com/info-budaya/1641-keadaan-dan-budaya-malang.html http://www.malang-guidance.com/kesenian-kebudayaan-kota-malang/ http://id.wikipedia.org/wiki/Kota_Malang 